Open Access at : http://jurnal.umt.ac.id/index.php/replik/index

\title{
KONSEP FIKTIF POSITIF: Penerapannya di Pengadilan Tata Usaha Negara
}

\author{
Ahmad \\ Fakultas Hukum Universitas Muhammadiyah Tangerang \\ Email: ahmad.law@gmail.com
}

\begin{abstract}
Abstrak
Fiktif positif merupakan satu konsep tentang relasi dan komunikasi antara warga masyarakat dengan pemerintah dalam penyelenggaraan adminitrasi pemerintahan atas suatu permohonan warga masyarakat dalam waktu tertentu tidak direspon oleh pemerintah dianggap permohonan dikabulkan. Terobosan baru ini merupakan antitesa atas konsep fiktif negatif yang dianut dalam undang-undang peradilan tata usaha negara yakni jika warga masyarakat mengajukan permohonan dalam batas waktu tertentu dan tidak ada respons dari pemerintah maka permohonan tersebut dianggap ditolak. Permohonan fiktif positif dimaksudkan untuk mendapatkan kepastian hukum dengan mengajukan permohonan kepada Pengadilan Tata Usaha Negara untuk mendapatkan keputusan. Bentuk permohonan seperti apa yang dapat diajukan kepada PTUN agar mendapatkan keputusan merupakan persoalan dalam penelitian ini. Metode penelitian yang digunakan dalam penelitian ini adalah penelitian library research/studi kepustakaan dan putusan pengadilan tata usaha negara No. 17/P/FP/2017/PTUN.JKT dengan menggunakan pendekatan analisis deskriptif. Adapun hasil penelitian ini, permohonan fiktif positif menurut ketentuan dalam undang-undang adminitrasi pemerintahan tidak menentukan secara jelas dan tegas bentuk permohonannya harus merupakan permohonan baru atau permohonan dalam bentuk lain sehingga Pengadilan Tata Usaha Negara Jakarta melakukan penemuan hukum. Adapun permohonan keberatan atas pembatalan ijin yang pernah diberikan oleh badan dan/atau pejabat sebagaimana putusan putusan pengadilan tata usaha negara yang digunakan penulis dalam melakukan analisis tulisan ini menurut putusan putusan pengadilan tata usaha negara Jakarta bukan merupakan permohonan fiktif positif. Adanya syarat yang menjadi obyek permohonan fiktif positif
\end{abstract}


haruslah permohonan yang baru menjadikan semangat dalam perbaikan pelayanan adminitrasi pemerintah bertentangan dengan spirit dari pembentukan undangundang adminitrasi pemerintahan sehingga konsep fiktif positif dalam undangundang adminitrasi pemerintahan harus dipertegas landasan hukumnya mengenai bentuk permohonan fiktif positif.

Kata Kunci: Permohonan Fiktif Positif, Adminitrasi Pemerintahan, Pengadilan Tata Usaha Negara.

\section{PENDAHULUAN}

Undang-Undang Nomor 30 Tahun 2014 tentang Administrasi Pemerintahan (UU AP) merupakan perwujudan kehendak pembentuk undang-undang untuk memperbaiki administrasi pemerintahan. Diundangkannya UU AP pada tanggal 17 Oktober 2014, dipandang sebagai langkah progresif dalam melakukan reformasi administrasi pemerintahan. Hal ini antara lain karena UU AP dianggap makin menegaskan tanggungjawab negara dan pemerintah demi menjamin terselenggaranya pemerintahan yang berorientasi pada pelayanan publik yang cepat, nyaman, dan murah. Atas dasar itulah, UU AP diletakkan sebagai salah satu pilar reformasi birokrasi dan tata kelola pemerintahan yang baik. ${ }^{1}$

Apalagi, UU AP menggeser paradigma lama administrasi pemerintahan ke paradigma yang baru. Paradigma tersebut mengiringi arah paradigma pelayanan publik dalam penyelenggaraan administrasi pemerintahan yang makin berkembang, terutama seiring dengan era keterbukaan yang menuntut akses informasi seluasluasnya untuk publik. Hal demikian niscaya mengingat tugas-tugas pemerintahan yang kian kompleks, baik mengenai sifat pekerjaan, jenis tugas maupun mengenai orang-orang yang melaksanakan. Pada konteks inilah, muncul kebutuhan dalam penetapan standar layanan minimal dalam penyelenggaraan administrasi negara

${ }^{1}$ M. Guntur Hamzah, makalah disampaikan pada seminar sehari dalam rangka HUT Peradilan Tata Usaha Negara ke-26 dengan tema: Paradigma Baru Penyelenggaraan Pemerintahan Berdasarkan Undang-Undang Administrasi Pemerintahan, kaitannya dengan Perkembangan Hukum Acara Peratun, yang diselenggarakan di Hotel Mercure, Jakarta, 26 Januari 2016, hal 1-2. 
sehari-hari, termasuk kebutuhan untuk memberikan perlindungan hukum terhadap masyarakat sebagai user dari pekerjaan pelaksana administrasi negara. ${ }^{2}$

Dalam konsideran menimbang UU AP menegaskan hal-hal yakni dalam rangka meningkatkan kualitas penyelenggaraan pemerintahan, badan dan/atau pejabat pemerintahan dalam menggunakan wewenang harus mengacu pada asas-asas umum pemerintahan yang baik (AUPB) dan berdasarkan ketentuan peraturan perundangundangan. Untuk menyelesaikan permasalahan dalam penyelenggaraan pemerintahan, pengaturan mengenai administrasi pemerintahan diharapkan dapat menjadi solusi dalam memberikan pelindungan hukum, baik bagi warga masyarakat maupun pejabat pemerintahan. Untuk mewujudkan pemerintahan yang baik, khususnya bagi pejabat pemerintahan, undang-undang tentang administrasi pemerintahan menjadi landasan hukum yang dibutuhkan guna mendasari keputusan dan/atau tindakan pejabat pemerintahan untuk memenuhi kebutuhan hukum masyarakat dalam penyelenggaraan pemerintahan. $^{3}$

Uraian tersebut diatas menegaskan semangat pemerintah dalam peningkatan kualitas penyelenggaraan pemerintahan yang baik harus berlandaskan pada asas-asas umum pemerintahan yang baik dan berdasarkan peraturan perundang-undangan yang berlaku, terutama dalam pelayanan kepada masyarakat yang sering ditemukan tidak memberikan jaminan dan ketidakpastian hukum dalam memberikan keputusan dan/atau tindakan pejabat pemerintahan dibidang pelayanan adminitrasi pemerintahan.

Undang-undang tentang administrasi pemerintahan dimaksudkan sebagai salah satu dasar hukum bagi badan dan/atau pejabat pemerintahan, warga masyarakat, dan pihak-pihak lain yang terkait dengan administrasi pemerintahan dalam upaya meningkatkan kualitas penyelenggaraan pemerintahan. ${ }^{4}$ Undang-undang adminitrasi pemerintah mempunyai tujuan yakni menciptakan tertib penyelenggaraan administrasi pemerintahan, menciptakan kepastian hukum, mencegah terjadinya penyalahgunaan wewenang, menjamin akuntabilitas badan dan/atau pejabat pemerintahan, memberikan pelindungan hukum kepada warga masyarakat dan aparatur pemerintahan, melaksanakan ketentuan peraturan perundang-undangan dan

\footnotetext{
${ }^{2}$ Ibid

${ }^{3}$ Konsideran menimbang dalam Undang-Undang nomor 30 taun 2014 tentang Adminitrasi Pemerintahan.

${ }^{4}$ Pasal 2 Undang-Undang Adminitrasi Pemerintahan
} 
menerapkan AUPB; dan memberikan pelayanan yang sebaik-baiknya kepada warga masyarakat. $^{5}$

Sesuai dengan ketentuan Pasal 1 ayat (2) Undang-Undang Dasar Negara Republik Indonesia Tahun 1945 (UUD NRI 1945), kedaulatan berada di tangan rakyat dan dilaksanakan menurut Undang-Undang Dasar. Selanjutnya menurut ketentuan Pasal 1 ayat (3) UUD NRI 1945, negara Indonesia adalah negara hukum. Hal ini berarti bahwa sistem penyelenggaraan pemerintahan negara republik Indonesia harus berdasarkan atas prinsip kedaulatan rakyat dan prinsip negara hukum. Berdasarkan prinsip-prinsip tersebut, segala bentuk keputusan dan/atau tindakan administrasi pemerintahan harus berdasarkan atas kedaulatan rakyat dan hukum yang merupakan refleksi dari Pancasila sebagai ideologi negara. Dengan demikian tidak berdasarkan kekuasaan yang melekat pada kedudukan penyelenggara pemerintahan itu sendiri. Penggunaan kekuasaan negara terhadap warga masyarakat bukanlah tanpa persyaratan. warga masyarakat tidak dapat diperlakukan secara sewenang-wenang sebagai objek. keputusan dan/atau tindakan terhadap warga masyarakat harus sesuai dengan ketentuan peraturan perundang-undangan dan asas-asas umum pemerintahan yang baik. Pengawasan terhadap keputusan dan/atau tindakan merupakan pengujian terhadap perlakuan kepada warga masyarakat yang terlibat telah diperlakukan sesuai dengan hukum dan memperhatikan prinsip-prinsip perlindungan hukum yang secara efektif dapat dilakukan oleh lembaga negara dan peradilan tata usaha negara yang bebas dan mandiri. Karena itu, sistem dan prosedur penyelenggaraan tugas pemerintahan dan pembangunan harus diatur dalam undang-undang. ${ }^{6}$

Tugas pemerintahan untuk mewujudkan tujuan negara sebagaimana dirumuskan dalam pembukaan Undang-Undang Dasar Negara Republik Indonesia Tahun 1945 dan tugas tersebut merupakan tugas yang sangat luas. Begitu luasnya cakupan tugas Administrasi Pemerintahan sehingga diperlukan peraturan yang dapat mengarahkan penyelenggaraan Pemerintahan menjadi lebih sesuai dengan harapan dan kebutuhan masyarakat (citizen friendly), guna memberikan landasan dan pedoman bagi Badan dan/atau Pejabat Pemerintahan dalam menjalankan tugas penyelenggaraan pemerintahan.

\footnotetext{
${ }^{5}$ Pasal 3 Undang-Undang Adminitrasi Pemerintahan

${ }^{6}$ Penjelasan umum UndangUndang Nomor 30 Tahun 2014 tentang Adminitrasi Pemerintahan
} 
Ketentuan penyelenggaraan Pemerintahan tersebut diatur dalam sebuah Undang-Undang yang disebut Undang-Undang Administrasi Pemerintahan. UndangUndang Administrasi Pemerintahan menjamin hak-hak dasar dan memberikan pelindungan kepada Warga Masyarakat serta menjamin penyelenggaraan tugas-tugas negara sebagaimana dituntut oleh suatu negara hukum sesuai dengan Pasal 27 ayat (1), Pasal 28 D ayat (3), Pasal 28 F, dan Pasal 28 I ayat (2) UUD NRI 1945. Berdasarkan ketentuan tersebut, Warga Masyarakat tidak menjadi objek, melainkan subjek yang aktif terlibat dalam penyelenggaraan Pemerintahan. Dalam rangka memberikan jaminan pelindungan kepada setiap Warga Masyarakat, maka UndangUndang ini memungkinkan Warga Masyarakat mengajukan keberatan dan banding terhadap Keputusan dan/atau Tindakan, kepada Badan dan/atau Pejabat Pemerintahan atau Atasan Pejabat yang bersangkutan. ${ }^{7}$

Warga masyarakat juga dapat mengajukan gugatan terhadap keputusan dan/atau tindakan badan dan/atau pejabat pemerintahan kepada peradilan tata usaha negara, karena undang-undang ini merupakan hukum materiil dari sistem peradilan tata usaha negara. Undang-undang administrasi pemerintahan mengaktualisasikan secara khusus norma konstitusi hubungan antara negara dan warga masyarakat. Pengaturan administrasi pemerintahan dalam undang-undang ini merupakan instrumen penting dari negara hukum yang demokratis, dimana keputusan dan/atau tindakan yang ditetapkan dan/atau dilakukan oleh badan dan/atau pejabat pemerintahan atau penyelenggara negara lainnya yang meliputi lembaga-lembaga di luar eksekutif, yudikatif, dan legislative yang menyelenggarakan fungsi pemerintahan yang memungkinkan untuk diuji melalui pengadilan. Hal inilah yang merupakan nilai-nilai ideal dari sebuah negara hukum. Penyelenggaraan kekuasaan negara harus berpihak kepada warganya dan bukan sebaliknya. Undang-Undang ini diperlukan dalam rangka memberikan jaminan kepada warga masyarakat yang semula sebagai objek menjadi subjek dalam sebuah negara hukum yang merupakan bagian dari perwujudan kedaulatan rakyat. Kedaulatan warga masyarakat dalam sebuah negara tidak dengan sendirinya baik secara keseluruhan maupun sebagian dapat terwujud. Pengaturan administrasi pemerintahan dalam undang-undang ini menjamin bahwa keputusan dan/atau tindakan badan dan/atau pejabat pemerintahan terhadap warga masyarakat tidak dapat dilakukan dengan semena-mena. Dengan undang-undang ini, warga

\section{${ }^{7}$ Ibid}


masyarakat tidak akan mudah menjadi objek kekuasaan negara. selain itu, undangundang ini merupakan transformasi AUPB yang telah dipraktikkan selama berpuluhpuluh tahun dalam penyelenggaraan pemerintahan, dan dikonkretkan ke dalam norma hukum yang mengikat.

AUPB yang baik akan terus berkembang, sesuai dengan perkembangan dan dinamika masyarakat dalam sebuah negara hukum. Karena itu penormaan asas ke dalam Undang-Undang ini berpijak pada asas-asas yang berkembang dan telah menjadi dasar dalam penyelenggaraan pemerintahan di Indonesia selama ini. UndangUndang ini menjadi dasar hukum dalam penyelenggaraan pemerintahan di dalam upaya meningkatkan kepemerintahan yang baik (good governance) dan sebagai upaya untuk mencegah praktik korupsi, kolusi, dan nepotisme. Dengan demikian, UndangUndang ini harus mampu menciptakan birokrasi yang semakin baik, transparan, dan efisien.

Adapun yang menjadi obyek permohonan oleh PT. Riau Andalan Pulp and Paper (PT. RAPP) selaku pemohon dalam perkara No. 17/P/FP/2017/PTUN.JKT di PTUN adalah permohonan untuk mendapatkan putusan atas permohonan pencabutan surat keputusan atau keberatan yang diajukan Pemohon sebagaimana surat pemohon nomor 101/RAPP-DIR/X/2017 tertanggal 18 Oktober 2017 perihal: keberatan atas Surat Keputusan Menteri Lingkungan Hidupan dan Kehutanan Nomor SK 5322/MenlHK-PHPL/UHP/HPL.1/10/2017 tanggal 16 Oktober 2017, sementara yang menjadi Termohon adalah Kementerian Lingkungan Hidup dan Kehutanan (KLHK).

Permohonan fiktif positif dalam perkara No. 17/P/FP/2017/PTUN.JKT di PTUN Jakarta atas Surat Keputusan Menteri LHK pada 18 Oktober yang membatalkan persetujuan Revisi Rencana Kerja Usaha (RKU) PT RAPP untuk periode 2010 - 2019 dengan alasan pihak perusahaan menolak mengubah rencananya agar sesuai dengan aturan baru soal perlindungan lahan gambut. Sejak dibatalkannya RKU pada 16 Oktober yang lalu, dampak pembatalan ini adalah berhentinya seluruh kegiatan HTI di PT RAPP yang meliputi kegiatan penanaman, pembibitan, pemanenan, dan pengangkutan di seluruh area operasi PT. RAPP yang terdapat di lima kabupaten di Provinsi Riau yaitu Pelalawan, Kuantan Singingi, Siak, Kampar, dan Kepulauan Meranti.

Dalam SK Menteri LHK, PT RAPP diberi waktu untuk menyesuaikan RKU sesuai dengan PP No. 57 tahun 2016 dalam waktu sepuluh hari sejak SK tersebut 
diterbitkan (16 Oktober 2017). Paksaan itu diberikan karena setelah empat kali revisi, PT RAPP bersikeras untuk melakukan penanaman di lahan dengan fungsi lindung. Menteri LHK Siti Nurbaya melalui Surat Keputusan No 5322/MenLHK PHPL/UHP/HPL.1/10/2017 membatalkan RKU RAPP periode 2010-2019. SK itu memberi waktu 10 hari kerja hingga 30 Oktober kepada RAPP untuk memperbaiki RKU. ${ }^{8}$ Ketentuan peralihan yang tercantum dalam Pasal 45 Peraturan Pemerintah No 71/2014 tentang Perlindungan dan Pengelolaan Ekosistem Gambut menjamin kelanjutan izin usaha atau kegiatan yang sudah diberikan oleh penyelenggara pemerintahan hingga lisensi itu berakhir. Jaminan itu tetap ada sekalipun beleid kemudian diubah melalui PP No 57/2016.

Berdasarkan uraian sebagaimana yang dijelaskan di atas, telah menunjukan konsep fiktif positif tidak serta merta dapat dijalankan sesuai dengan semangat pembentukan norma tersebut kedalam norma UUAP tetapi terdapat permasalahan norma yang menyangkut bentuk permohonan yang dapat menjadi obyek permohonan untuk mendapatkan putusan dari pengadilan tata usaha Negara merupakan hal yang menarik untuk dikaji dan dianalisis secara mendalam.

\section{METODE PENELITIAN}

Jenis penelitian ini adalah penelitian pustaka yang sumber datanya diperoleh melalui penelitian terhadap berbagai literatur yang relevan dengan obyek penelitian. Sebagai sebuah penelitian yang menelusuri prinsip dan teori tentang konsep fiktif positif serta penerapannya dalam putusan Pengadilan Tata Usaha Negara, maka secara metodologis penelitian ini akan mengkaji konsep-konsep fiktif positif dan implementasinya di pengadilan tata usaha Negara Jakarta. Hal ini penting dilakukan karena hanya dari konsep fiktif positif dan implementasinnya di Pengadilan Tata Usaha Negara itulah dapat ditimba, diambil dan temukan makna atas norma-norma hokum tersebut dalam kontek praktiknya.

Adapun tipe penelitian ini adalah deskriptif analitis kualitatif, artinya penelitian dilakukan dengan mendeskripsikan, menganalisis secara kualitatif atas data yang berkaitan dengan obyek penelitian baik dalam hukum positif maupun putusan

${ }^{8}$ http://industri.bisnis.com/read/20171030/99/704318/serahkan-revisi-rku-rapp-tunggu-reviewklhk, dakses kamis tanggal 18 januari 2018 pukul 14.00 wib. 
Pengadilan Tata Usaha Negara Jakarta untuk menarik kesimpulan sesuai dengan pokok masalahnya.

\section{HASIL PENELITIAN DAN ANALISIS}

\section{A. Konsep Fiktif Positif}

Perbedaan Prinsip didalam Undang-Undang Peradilan Tata Usaha Negara dan Undang-Undang Administrasi Pemerintahan adalah aturan mengenai keputusan fiktif negatif dan keputusan fiktif positif. Pasal 3 Undang-Undang Peradilan Tata Usaha Negara mengatur mengenai keputusan fiktif negatif yaitu jika suatu Badan atau Pejabat Tata Usaha Negara tidak mengeluarkan keputusan yang dimohon sedangkan jangka waktu telah lewat, maka badan atau pejabat tata usaha negara dianggap telah menolak mengeluarkan keputusan yang dimaksud. ${ }^{9}$

Perubahan paradigma administrasi dalam UUAP 2014 yang penting digarisbawahi adalah berlakunya doktrin 'Fiktif Positif'. Fiktif, atau sikap diam Badan atau Pejabat TUN tersebut, merujuk pada Keputusan TUN yang tidak berwujud. Ini dapat dianggap sebagai suatu bentuk penolakan, atau pengabulan suatu permohonan. Jika Keputusan TUN yang tidak berwujud itu dianggap berisi penolakan terhadap permohonan yang diajukan, maka disebut sebagai 'Fiktif Negatif', sedangkan jika Keputusan TUN dianggap mengabulkan permohonan yang telah diajukan, maka disebut sebagai 'Fiktif Positif'. Ketentuan mengenai Keputusan Fiktif Negatif diatur dalam ketentuan Pasal 3 UU Peratun, sedangkan ketentuan mengenai Keputusan Fiktif Positif terdapat dalam Pasal 53 UUAP. ${ }^{10}$

Adapun Pasal 53 Undang-Undang Administrasi Pemerintahan secara prinsip mengatur apabila dalam batas waktu yang ditentukan, Badan atau Pejabat Pemerintahan tidak menetapkan dan atau melakukan keputusan dan/atau tindakan, maka permohonan tersebut dianggap dikabulkan secara hukum. Hal itulah yang dimaknai dengan keputusan fiktif positif. Lahirnya keputusan fiktif positif tidak lepas dari perubahan paradigma pelayanan publik yang mengharuskan badan atau pejabat

9 Sjachran Basah, Eksistensi dan Tolak Ukur Badan Peradilan Administrasi di Indonesia, Alumni : Bandung, 1989, hal. 3-4. Lihat Donna O. Setiabudhi, Makalah, Keputusan Fiktif Negatif Sebagai Dasar Pengajuan Gugatan Dalam Sengketa Tata Usaha Negara Yang Berkaitan Dengan Pelayanan Dalam Bidang Pertanahan, Universitas Sam Ratulangi Fakultas Hukum, Manado, 2014, hal. 5

${ }^{10}$ Herlambang dkk, Asas-asas Umum Pemerintahan Yang baik dalam Perkara Tata Usaha Negara, Penelitian Sosio-Legal, 2017, hal. 8 
pemerintah lebih responsif terhadap permohonan masyarakat. Zudan Arif Fakrulloh mengatakan salah satu keinginan dasar dan arah politik hukum dalam UndangUndang Administrasi Pemerintahan adalah meningkatnya kualitas penyelenggaraan pemerintahan. ${ }^{11}$

Pengaturan terhadap Administrasi Pemerintahan pada dasarnya adalah upaya untuk membangun prinsip-prinsip pokok, pola pikir, sikap, perilaku, budaya dan pola tindak administrasi yang demokratis, objektif, dan professional dalam rangka menciptakan keadilan dan kepastian hukum. Undang-Undang ini merupakan keseluruhan upaya untuk mengatur kembali Keputusan dan/atau Tindakan Badan dan/atau Pejabat Pemerintahan berdasarkan ketentuan peraturan perundang-undangan dan AUPB. Undang-Undang ini dimaksudkan tidak hanya sebagai payung hukum bagi penyelenggaraan pemerintahan, tetapi juga sebagai instrumen untuk meningkatkan kualitas pelayanan pemerintahan kepada masyarakat sehingga keberadaan Undang-Undang ini benar-benar dapat mewujudkan pemerintahan yang baik bagi semua Badan atau Pejabat Pemerintahan di Pusat dan Daerah.

Udang-undang adminitrasi pemerintah mengatur asas-asas umum pemerintahan yang baik meliputi kepastian hukum, kemanfaatan, ketidakberpihakan, kecermatan, tidak menyalahgunakan kewenangan, keterbukaan, kepentingan umum; dan pelayanan yang baik. Lebih lanjut dalam penjelasan Pasal 10 menjelaskan asas-asas AUPB yaitu; a) asas kepastian hukum adalah asas dalam negara hukum yang mengutamakan landasan ketentuan peraturan perundang-undangan, kepatutan, keajegan, dan keadilan dalam setiap kebijakan penyelenggaraan pemerintahan; b) asas kemanfaatan adalah manfaat yang harus diperhatikan secara seimbang antara:(1) kepentingan individu yang satu dengan kepentingan individu yang lain; (2) kepentingan individu dengan masyarakat; (3) kepentingan Warga Masyarakat dan masyarakat asing; (4) kepentingan kelompok masyarakat yang satu dan kepentingan kelompok masyarakat yang lain; (5) kepentingan pemerintah dengan Warga Masyarakat; (6) kepentingan generasi yang sekarang dan kepentingan generasi mendatang; (7) kepentingan manusia dan ekosistemnya; (8) kepentingan pria dan wanita; c) asas ketidakberpihakan adalah asas yang mewajibkan Badan dan/atau Pejabat Pemerintahan dalam menetapkan dan/atau melakukan Keputusan dan/atau

11 Zudan Arif Fakrulloh, Tindakan Hukum Bagi Aparatur Penyelenggara Pemerintahan, Seminar Nasional IKAHI ke 62, Jakarta 26 Maret 2015, hal 6 
Tindakan dengan mempertimbangkan kepentingan para pihak secara keseluruhan dan tidak diskriminatif; d) asas kecermatan adalah asas yang mengandung arti bahwa suatu Keputusan dan/atau Tindakan harus didasarkan pada informasi dan dokumen yang lengkap untuk mendukung legalitas penetapan dan/atau pelaksanaan Keputusan dan/atau Tindakan sehingga Keputusan dan/atau Tindakan yang bersangkutan dipersiapkan dengan cermat sebelum Keputusan dan/atau Tindakan tersebut ditetapkan dan/atau dilakukan; e) asas tidak menyalahgunakan kewenangan adalah asas yang mewajibkan setiap Badan dan/atau Pejabat Pemerintahan tidak menggunakan kewenangannya untuk kepentingan pribadi atau kepentingan yang lain dan tidak sesuai dengan tujuan pemberian kewenangan tersebut, tidak melampaui, tidak menyalahgunakan, dan/atau tidak mencampuradukkan kewenangan; f) asas keterbukaan adalah asas yang melayani masyarakat untuk mendapatkan akses dan memperoleh informasi yang benar, jujur, dan tidak diskriminatif dalam penyelenggaraan pemerintahan dengan tetap memperhatikan perlindungan atas hak asasi pribadi, golongan, dan rahasia Negara; g) asas kepentingan umum adalah asas yang mendahulukan kesejahteraan dan kemanfaatan umum dengan cara yang aspiratif, akomodatif, selektif, dan tidak diskriminatif; h) asas pelayanan yang baik adalah asas yang memberikan pelayanan yang tepat waktu, prosedur dan biaya yang jelas, sesuai dengan standar pelayanan, dan ketentuan peraturan perundang-undangan; i) asas-asas umum lainnya di luar AUPB adalah asas umum pemerintahan yang baik yang bersumber dari putusan pengadilan negeri yang tidak dibanding, atau putusan pengadilan tinggi yang tidak dikasasi atau putusan Mahkamah Agung

\section{B. Penerapan fiktif positif di Pengadilan Tata Usaha Negara.}

Adapun dasar permohonan fiktif positif telah ditentukan Pasal 53 UU AP yang mengatur :

1. Batas waktu kewajiban untuk menetapkan dan/atau melakukan keputusan dan/atau tindakan sesuai dengan ketentuan peraturan perundang-undangan.

2. Jika ketentuan peraturan perundang-undangan tidak menentukan batas waktu kewajiban sebagaimana pada ayat (1), maka Badan dan/atau Pejabat Pemerintahan wajib menetapkan dan/atau melakukan keputusan dan/atau tindakan dalam waktu paling lama 10 (sepuluh) hari kerja setelah 
permohonan diterima secara lengkap oleh Badan dan/atau Pejabat Pemerintahan.

3. Apabila dalam batas waktu sebagaimana dimaksud pada ayat (2), Badan dan/atau Pejabat pemerintahan tidak menetapkan dan/atau melakukan keputusan dan/atau tindakan, maka permohonan tersebut dianggap dikabulkan.

4. Pemohon mengajukan permohonan kepada pengadilan untuk memperoleh keputusan penerimaan permohonan sebagaimana dimaksud pada ayat (3).

5. Pengadilan wajib memutuskan permohonan sebagaimana dimaksud pada ayat (4) paling lama 21 (dua puluh satu) hari kerja sejak permohonan diajukan.

Sementara ketentuan hukum acara permohonan diatur lebih lanjut dalam Pasal 3 ayat (1) Peraturan Mahkamah Agung RI nomor 5 tahun 2015 tentang Pedoman Beracara Untuk Memperoleh Putusan Atas Penerimaan Permohonan Guna Mendapatkan Keputusan Dan/Atau Tindakan Badan Atau Pejabat Pemerintahan (perma no 5 tahun 2015). Perma t nomor 5 tahun 2015 menentukan permohonan diajukan kepada pengadilan yang wilayah hukumnya meliputi tempat kedudukan Termohon melalui kepaniteraan. Perma nomor 5 tahun 2015 mengatur lebih lanjut tentang pemeriksaan persidangan adalah pemeriksaan pokok permohonan, pemeriksaan tanggapan termohon, pemeriksaan bukti surat atau tulisan, mendengarkan keterangan saksi, mendengarkan keterangan ahli dan pemeriksaan alat bukti lain yang berupa informasi elektronik atau dokumen elektronik.

Baik Pasal 53 UU AP maupun Perma 5 tahun 2015 tidak mengatur secara rinci dan jelas tentang kriteria keputusan dan/atau tindakan apa saja yang dapat dimohonkan kepada Badan atau Pejabat pemrintahan yang apabila tidak ditanggapi dalam waktu yang telah ditentukan oleh peraturan perundang-undangan maka dalam waktu 10 (sepuluh) hari kerja, maka permohonan tersebut dianggap dikabulkan secara hukum dan oleh pemohon dapat mengajukan permohonan kepada pengadilan untuk memperoleh putusan penerimaan permohonan tersebut sementara pada sisi lain Pasal 53 UU Nomor 51 Tahun 12009 tentang pengadilan Tata Usaha Negara mengatur langkah hukum berupa gugatan biasa yang dapat diajukian oleh masyarakat yang merasa kepentingannya dirugikan terhadap keputusan badan atau pejabat tata usaha Negara. 
Terhadap permasalahan hukum yang dimohonkan oleh pemohon maka pengadilan tata usaha Negara Jakarta dengan melakukan judicial activism atas dasar penilain adanya norma yang kurang jelas (sumir) untuk menentukan kriteria permohonan apa saja yang dapat dimohonkan kepada Badan atau Pejabat Pemerintahan yang dapat digunakan untuk memperoleh putusan penerimaan permohonan agar tidak terjadi tumpang tindih atau kekacauan hukum antara pengajuan permohonan keputusan fiktif positif dan gugatan biasa ke pengadilan tata usaha negara. Kegiatan pembentukan hukum oleh hakim berdasarkan Pasal 5 ayat (1) dan Pasal 10 ayat (1) Undang-Undang Nomor 48 Tahun 2009 tentang kekuasaan kehakiman; "hakim dan hakim konstitusi wajib menggali, mengikuti dan memahami nilai-nilai hukum dan rasa keadilan yang hidup dalam masyarakat”. Pasal 10 ayat (1) mengatur; "pengadilan dilarang menolak untuk memeriksa, mengadili dan memutus suatu perkara yang diajukan dengan dalil bahwa hukum tidak ada atau kurang jelas, melainkan wajib untuk memeriksa dan mengadilinya.

Ketentuan tersebut diatas menegaskan betapa pentingnya peran hakim dan hakim konstitusi sehingga wajib menggali dan memahami nilai-nilai hukum dan rasa keadilan masyarakat atas setiap permohonan perkara yang diajukan oleh masyarakat yang harus diperiksa, diadili dan diputuskan bukan menolak untuk memeriksa, mengadili dan memutuskan dengan alasan tidak ada hukum atau tidak jelas hukumnya.

Eksistensi PTUN dalan suatu negara hukum merupakan pilar untuk mengakan hukum dan keadilan dalam masyarakat, disamping itu dapat melakukan kontrol terhadap tindakan pemerintah, yaitu melalui pengujian keabsahan keputusan tata usaha negara dan diwujudkan dalam bentuk putusan hakim. Dalam tugasnya untuk melakukan pengujian terhadap keabsahan beschikking yang dikeluarkan oleh pemerintah, pengujian tersebut harus berdasarkan kepada peraturan perundangundangan yang berlaku dan AUPB. Undang-undang sebagai dasar pengujian Keputusan Tata Usaha Negara (KTUN) tidak selalu lengkap, sempurna, tidak atau kurang jelas, kabur, oleh karena itu hakim harus melengkapi, menjelaskan agar undang-undang tersebut dapat diterapkan dalam peristiwanya. Hal tersebut dapat dilakukan oleh hakim melalui penafsiran atau intepretasi hukum. Hakim dalam tugasnya dilarang menolak suatu perkara yang diajukan kepadanya dengan alasan hukum kurang atau tidak jelas, melainkan hakim wajib untuk memahami, 
memperhatikan dan menggali nilai-nilai hukum dan rasa keadilan dalam masyarakat sebagaimana diamanahkan oleh UU Nomor 48 Tahun 2009 tentang Kekuasaan kehakiman $^{12}$

Dalam perkara yang dimohonkan oleh PT. RAPP telah memberikan dua pandangan yang berbeda antara ahli yang diajukan oleh pemohon (PT. RAPP) dengan keterangan ahli yang diajukan oleh pihak pemerintah yakni kementerian lingkungan hidup dan kehutanan selaku termohon terkait dengan obyek perkara dalam permohonan fiktif positif, sebagaimana yang gambarkan dalam table dibawah ini.

Tabel Pembanding Keterangan Ahli Pemohon dan Termohon

\begin{tabular}{|c|c|c|}
\hline No. & Keterangan Ahli Pemohon & Keterangan ahli Termohon \\
\hline 1. & $\begin{array}{l}\text { Dr. Dian Puji N. SImatupang, SH., } \\
\text { MH } \\
\text { - Semua bentuk permohonan } \\
\text { menjadi obyek permohonan } \\
\text { fiktif positif. }\end{array}$ & $\begin{array}{l}\text { Prof. Dr. Zudan Arif Fakrullah, SH., MH } \\
\text { - } \text { Obyek permohonan fiktif positif } \\
\text { merupakan permohonan hak yang baru } \\
\text { bukan untuk membatalkan keputusan } \\
\text { yang sudah terjadi. }\end{array}$ \\
\hline 2. & $\begin{array}{l}\text { Dr. Lintong Oloan Siahaan, SH., } \\
\text { MH } \\
\text { - } \quad \text { Pasal } 77 \text { dan Pasal } 53 \text { UU AP } \\
\text { bersinggungan sehingga } \\
\text { keberatan atas permohonan } \\
\text { merupakan obyek Permohonan } \\
\text { fiktif positif }\end{array}$ & $\begin{array}{l}\text { Prof. Dr. Philipus M. Hadjon, SH } \\
\text { - Pembatalan suatu keputusan atau } \\
\text { tindakan dilakukan lewat gugatan } \\
\text { bukan permohonan fiktif positif. }\end{array}$ \\
\hline
\end{tabular}

Menurut Santer Sitorus $^{13}$ mengatakan bahwa cakupan permohonan yang dimaksud dalam UU AP adalah permohonan untuk menerbitkan keputusan yang sifatnya baru dan bukan pembatalan keputusan yang sudah ada. Hal ini juga diperkuat oleh Prof. Eko Prasojo yang melihat bahwa dalam konstruksi Pasal 53 UUAP,

${ }^{12}$ Suhartono, Membangun Konstruksi Hakim dalam Penemuan Hukum oleh Pengadilan Tata Usaha Negara, Disertasi Universitas Sebelas Maret Surakarta, 2012, hal. xiii

${ }^{13}$ Anotasi UUAP yang diterbitkan oleh Universitas Indonesia-Center for Study of Governance and Adminitrative (UI.CSGAR), tahun 2017, bab 5, hal. 233. Lihat pertimbangan Putusan no. 17/P/FP/2017/PTUN-JKT, hal 153. 
terutama dalam batas waktu, disini terlihat bahwa permohonann yang sudah ada batas waktu untuk diproses, misalnya yang berkaitan dengan izin, kompensasi dan sebagainya, yang lazimnya digunakan untuk memproses permohonan baru atau perpanjangan permohonan.

Pada akhirnya permohonan pemohon (PT. RAPP) selaku pemohon melawan kementerian lingkungan hidup dan kehutanan selaku termohon dalam perkara permohonan fiktif positif oleh pengadilan tata usaha negara Jakarta memerikan putusan yakni menolak permohonan pemohon dengan alasan permohonan pemohon bukan merupakan obyek permohonan fiktif positif melain harus dilakukan dengan gugatan biasa.

Putusan PTUN Jakarta tersebut mengambilalih keterangan ahli yang diajukan oleh kementerian negara lingkungan hidup dan kehutanan yang menegaskan bahwa obyek permohonan dalam permohonan fiktif positif adalah permohonan baru bukan permohonan keberatan atas pembatalan rencana kerja usaha yang dimohonkan oleh Pemohon (PT. RAPP) meskipun menurut ketentuan UUAP tidak menentukan kriteria bentuk permohonan yang dapat menjadi obyek permohonan fiktif positif. Sesungguhnya permohonan Pemohon yang diputus oleh PTUN Jakarta masih dalam ruang lingkup syarat formil sutau permohonan belum menyangkut pokok permohonan. Terhadap putusan tersebut, pihak Pemohon (PT. RAPP) masih dapat melakukan langkah hukum dengan mengajukan gugatan biasa kepada pengadilan tata usaha Negara.

\section{PENUTUP}

\section{A. Simpulan}

1. Konsep fiktif positif merupakan relasi dan komunikasi antara warga masyarakat dengan pemerintah dalam penyelenggaraan adminitrasi pemerintahan atas setiap permohonan yang diajukan oleh warga masyarakat dalam waktu tertentu tidak direspon oleh pemerintah maka permohonan tersebut dianggap permohonan dikabulkan sehingga dapat ajukan permohonan putusan kepada pengadilan tata usaha Negara.

2. Adapun bentuk permohonan fiktif positif yang dimaksud dalam undangundang adminitrasi pemerintahan sebagaimana yang dimaksud dalam putusan perkara No. 17/P/FP/2017/PTUN.JKT di PTUN Jakarta antara PT. 
Riau Paper (Pemohon) melawan Kementerian lingkungan hidup dan kehutanan (KLHK) haruslah permohonan baru bukan permohonan keberatan atas pembatalan ijin yang dilakukan oleh badan dan atau pejabat tata usaha Negara. Putusan tersebut telah bertentangan dengan semangat yang diatur dalam undang-undang adminitrasi pemerintahan yang menghendaki adanya tindakan responsive dari badan dan atau pejabat tata usaha Negara atas setiap permohonan yang tidak direspon haruslah dianggap dikabulkan sehingga dalam perkara tersebut PTUN Jakarta berwenang mengadili dan memutusnya bukan dengan menjatuhkan putusan dengan menyatakan permohonan pemohon bukan obyek permohonan fiktif positif.

\section{B. Saran}

1. Perlu adanya perubahan atas UUAP secara khusus Pasal yang mengatur mengenai obyek permohonan dalam perkara fiktif positif dan agar tidak hanya terbatas pada permohonan baru saja.

2. Putusan fiktif positif yang pernah dibuat oleg Pengadilan Tata Usaha Negara Jakarta masih jauh dari rasa keadilan dan semangat yang terkandung dalam konsep fiktif positif sehingga pengadilan perlu mengmbil keputusan yang responsive atas setiap permohonan fiktif positif.

\section{DAFTAR PUSTAKA}

\section{Peraturan Perundang-undangan}

Undang-Undang nomor 30 tahun 2014 tentang Adminitrasi Pemerintahan.

Undang-Undang Nomor 48 Tahun 2009 tentang kekuasaan kehakiman.

Undang-Undang Nomor 51 Tahun 2009 tentang Perubahan Kedua Atas UndangUndang Nomor 5 Tahun 1986 Tentang Peradilan Tata Usaha Negara.

Peraturan Mahkamah Agung RI Nomor 5 Tahun 2015 tentang Pedoman Beracara Untuk Memperoleh Putusan Atas Penerimaan Permohonan Guna Mendapatkan Keputusan Dan/Atau Tindakan Badan Atau Pejabat Pemerintahan. 


\section{Buku-buku, Makalah dan Jurnal}

Anotasi Undang-Undang Nomor 30 Tahun 2014 tentang Adminitrasi Pemerintahan yang diterbitkan oleh Universitas Indonesia-Center for Study of Governance and Adminitrative (UI.CSGAR), tahun 2017.

Basah, Sjachran, 1989, Eksistensi dan Tolak Ukur Badan Peradilan Administrasi di Indonesia, Bandung, Alumni.

Suhartono, 2012, Membangun Konstruksi Hakim dalam Penemuan Hukum oleh Pengadilan Tata Usaha Negara, Disertasi Universitas Sebelas Maret Surakarta.

Donna O. Setiabudhi, Makalah, Keputusan Fiktif Negatif Sebagai Dasar Pengajuan Gugatan Dalam Sengketa Tata Usaha Negara Yang Berkaitan Dengan Pelayanan Dalam Bidang Pertanahan, Universitas Sam Ratulangi Fakultas Hukum, Manado, 2014.

Herlambang dkk, 2017, Asas-asas Umum Pemerintahan Yang baik dalam Perkara Tata Usaha Negara, Penelitian Sosio-Legal.

Hamzah, M. Guntur, 2016, makalah disampaikan pada seminar sehari dalam rangka HUT Peradilan Tata Usaha Negara ke-26 dengan tema: Paradigma Baru Penyelenggaraan Pemerintahan Berdasarkan Undang-Undang Administrasi Pemerintahan, kaitannya dengan Perkembangan Hukum Acara Peratun, yang diselenggarakan di Hotel Mercure, Jakarta.

Fakrulloh, Zudan Arif, 2015, Tindakan Hukum Bagi Aparatur Penyelenggara Pemerintahan, Seminar Nasional IKAHI ke 62, Jakarta.

\section{Website}

http://industri.bisnis.com/read/20171030/99/704318/serahkan-revisi-rku-rapp-tunggureview-klhk 